\title{
PENYIASATAN SECARA INISIATIF KANAK-KANAK MENERUSI PENDEKATAN PROJEK
}

\author{
Children's Initiative in Investigation Through Project Approach
}

\section{Noor Ashikin Mohd Yusop' ${ }^{1}$, Norazizah Abdul Rahman², Sopia Md Yassin ${ }^{3}$, Zainiah@Zaniah Mohamed Isa ${ }^{4}$}

Pusat Penyelidikan Perkembangan Kanak-Kanak Negara, Kampus Sultan Azlan Shah, Universiti Pendidikan Sultan Idris, 35900 Tanjong Malim, Perak, Malaysia. noorashikinmohdyusop@gmail.com ${ }^{1}$,norazizahabdulrahman@gmail.com ${ }^{2}$ sopia@fsmt.upsi.edu.my ${ }^{3}$, zainiah@fppm.upsi.edu.my ${ }^{4}$

\begin{abstract}
ABSTRAK
Tujuan kajian ini ialah untuk meneroka pelaksanaan penyiasatan secara inisiatif kanak-kanak. Secara khususnya kajian ini memberi maklumat tentang elemen-elemen penyiasatan secara inisiatif kanak-kanak menerusi Pendekatan Projek. Kajian ini dijalankan terhadap dua orang pendidik berserta dua kumpulan fokus kanak-kanak yang berusia 4+ dan 5+ di sebuah tadika di negeri Perak. Kajian kualitatif ini menggunakan reka bentuk kajian pelbagai kes. Data kajian diperoleh menerusi dokumen dan pemerhatian terhadap peserta kajian. Dapatan kajian menunjukkan bahawa elemen-elemen pelaksanaan aktiviti penyiasatan secara inisiatif kanak-kanak dapat ditonjolkan menerusi soalan kanak-kanak, pemilihan bahan dan alat radas, tatacara pelaksanaan penyiasatan dan penghasilan projek. Lantaran itu, hasil kajian ini membuktikan bahawa penyiasatan secara inisiatif kanak-kanak mampu meningkatkan penguasaan konsep sains kanak-kanak.
\end{abstract}

Kata Kunci: pendekatan projek, inisiatif kanak-kanak, inkuiri, sains

\begin{abstract}
The purpose of this study is to explore children's investigations have on their initiatives. Specifically, this study provides information on elements of a child-initiated investigation through Project Approach. This study was conducted involving two educators and two focus groups of children aged $4+$ and $5+$ in a kindergarten in Perak. This qualitative study used a multi-case study design. The data were obtained through documents and observations with the participants. The findings also showed that the elements of child initiatives can be highlighted through the children's questions, how children solve problems and project creation. Therefore, the finding also showed that the inquiry by children can also improve the concept science.
\end{abstract}

Keywords: project approach, child initiative, inquiry, science

\section{PENDAHULUAN}

Penyiasatan secara inisiatif merupakan proses pembelajaran yang memberi peluang penerokaan dan pembinaan pengetahuan baharu menerusi persoalan yang ditimbulkan oleh kanak-kanak sendiri. Menurut Helm dan Katz (2011), pembelajaran menerusi penyiasatan mendalam mengenai sesuatu topik dapat meningkatkan daya intelektual serta memberi peluang pengaplikasian kemahiran proses sains asas oleh kanak-kanak. Malah, menerusi pengalaman penyiasatan yang dilaksanakan menerusi aktiviti penerokaan di dalam dan luar bilik darjah dapat membina semula konsepsi sains kanak-kanak terhadap sesuatu fenomena (Helm \& Katz, 2011; Harlen, 2014). 
Justeru, pendidik memainkan peranan penting sebagai perancang aktiviti penyiasatan yang bersesuaian dengan tahap dan minat yang ditunjukkan oleh kanak-kanak. Dengan itu, pendidik bertindak sebagai pendengar, pemerhati serta memahami setiap tingkah laku dan idea kanak-kanak bagi menyokong pengalaman pembelajaran yang berkesan menerusi penyiasatan (Musgrove \& Taylor, 2012). Malah, jaringan interaksi sosial yang wujud di antara kanak-kanak dengan pendidik, pakar, ibu bapa dan rakan sebaya juga merupakan elemen penting yang turut menyokong pembentukan dan penguasaan pengetahuan baharu dalam proses penerokaan dan penyiasatan kanak-kanak (Noriati Rashid, Pong \& Sharifah Fakhriah Syed Ahmad, 2012).

Di samping itu, pelbagai pendekatan pengajaran dan pembelajaran boleh digunakan oleh pendidik meningkatkan fokus dan penglibatan aktif kanak-kanak. Selain itu, guru juga dapat meneliti dan menyelidiki idea sedia ada kanak-kanak. Menurut Helm dan Katz (2015), aktiviti pembinaan web kanak-kanak menerusi Pendekatan Projek mampu membantu pendidik mencungkil pengetahuan sedia ada kanak-kanak mengenai topik yang dibincangkan. Malah, pendidik juga berpeluang mengenal pasti punca wujudnya percanggahan idea kanak-kanak. Seterusnya, penyiasatan mendalam secara 'real life' berdasarkan persoalan yang dikemukakan oleh kanak-kanak dilaksanakan bagi mendapatkan informasi yang betul dan secara tidak langsung dapat menangani masalah konsepsi kanak-kanak.

Dalam kajian ini, penyiasatan secara inisiatif didefinisi sebagai pengalaman penyelidikan yang dibina sendiri oleh kanak-kanak. Sehubungan itu, kanak-kanak mengambil langkah yang pertama dalam melakukan sebarang aktiviti penerokaan dan penyiasatan sama ada secara individu, berkumpulan atau melibatkan orang dewasa. Namun demikian, penyelidik juga mengambil kira bahawa pengalaman yang dibentuk turut melibatkan peranan pendidik sebagai perancah bagi menyokong pembelajaran secara inisiatif selagi kanak-kanak dapat memperoleh pengalaman sebagai penyiasat dalam menentukan aktiviti yang akan diterokai.

Sehubungan itu, Pendekatan Projek juga turut memberi peluang penerokaan pembelajaran kepada kanak-kanak secara autentik dalam membina pengetahuan tentang dunia mereka (Helm \& Katz, 2015) seperti ditunjukkan dalam Rajah 1.

Sebagai ciri tambahan, Pendekatan Projek menekankan aspek penerokaan pembelajaran berasaskan minat dan inisiatif kanak-kanak (Helm \& Katz, 2011). Kanak-kanak juga membuat keputusan dalam pembelajaran menerusi aktiviti projek. Walau bagaimanapun, menerusi kaedah pengajaran secara unit dan bertema, peranan pendidik menjadi faktor utama dalam menggerakkan sesuatu aktiviti pembelajaran. Kanak-kanak kurang berperanan dalam membuat sebarang keputusan dalam melakukan penerokaan terhadap topik pembelajaran malah inisiatif kanak-kanak tidak ditonjolkan dalam aktiviti penyiasatan kerana pendidik telah menentukan kandungan dan konsep yang perlu dikuasai oleh kanak-kanak. 


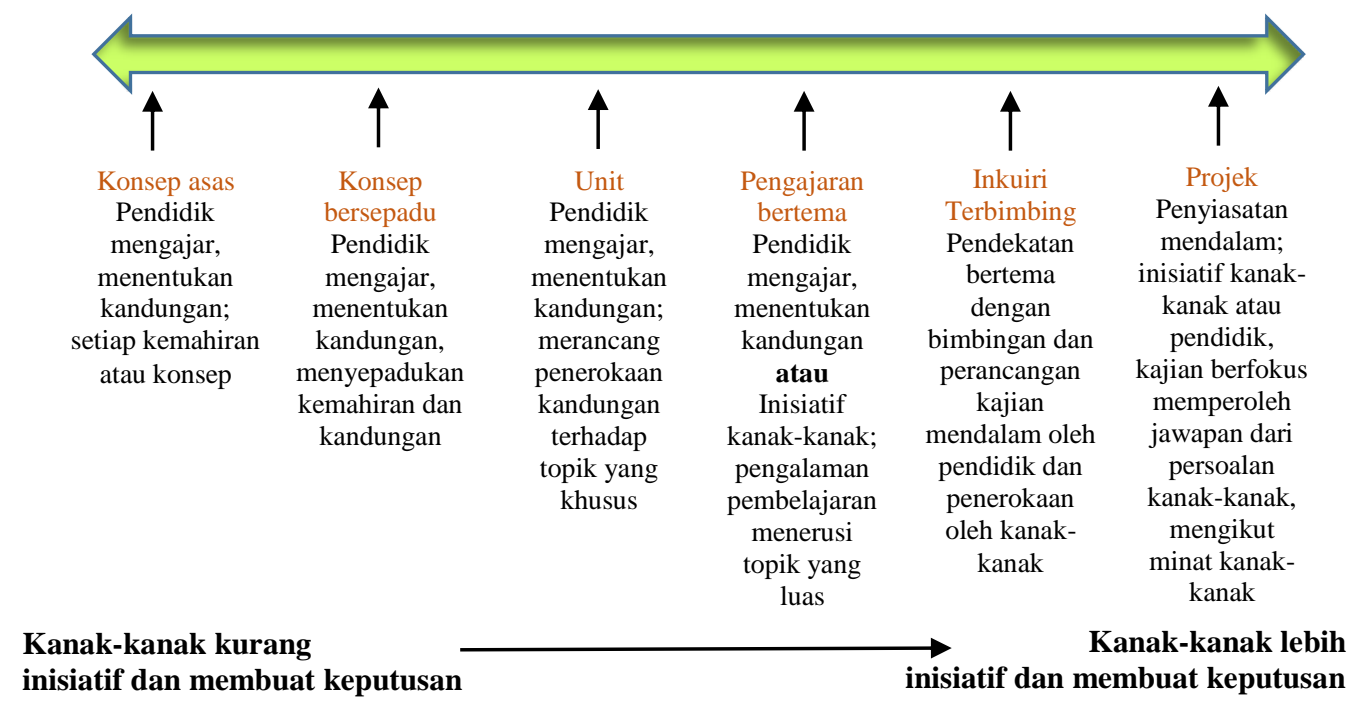

Rajah 1: Tahap inisiatif dan membuat keputusan kanak-kanak dalam pendekatan pengajaran yang berbeza (Helm \& Katz, 2011).

Justeru, aspek sosial dan pemahaman kanak-kanak mengenai dunia sebenar di sekeliling mereka dapat diperkukuhkan menerusi aktiviti projek. Hubungan kolaborasi kanakkanak dengan pakar semasa melakukan penyiasatan di tapak lapangan mahupun dalam bilik darjah, dapat meningkatkan pengetahuan kanak-kanak ke tahap yang lebih tinggi (Vygotsky 1978). Pelbagai penyiasatan serta penggabungjalinan antara tunjang pembelajaran seperti matematik, sains, moral dan bahasa juga merupakan antara kriteria yang terdapat dalam aktiviti projek. Contohyna, di samping menyiasat mengenai struktur rama-rama, kanak-kanak juga dapat menguasai konsep matematik. Kanak-kanak dapat mengira jumlah kaki, kepak, belalai dan antenna yang terdapat pada seekor rama-rama. Oleh itu, aktiviti projek dapat dijadikan sebagai pentas untuk kanak-kanak meluahkan perasaan ingin tahu dan mengalami pengalaman penyiasatan yang menyeronokkan, dengan adanya penyediaan sumber pembelajaran oleh pendidik mengikut minat dan idea yang dikemukakan oleh kanak-kanak.

\section{PEMBELAJARAN MENERUSI PENDEKATAN PROJEK}

Kurikulum Standard Prasekolah Kebangsaan 2010 telah memberi penekanan terhadap pembelajaran berasaskan projek. Walau bagaimanapun, tidak terdapat huraian terperinci cara pelaksanaan pendekatan tersebut. Walau bagaimanapun, Kementerian Pendidikan Malaysia (2015a) menjelaskan bahawa kaedah pengajaran dan pembelajaran sains menerusi projek merupakan suatu aktiviti yang dijalankan secara individu atau kumpulan. Pelaksanaan aktiviti projek ini mengambil masa yang panjang serta menjangkau waktu pembelajaran formal. Kanak-kanak berperanan dalam mengenal pasti kaedah untuk menyelesaikan sesuatu masalah telah dikemukakan dan seterusnya merancang keseluruhan projek. Hasil projek dipersembahkan dalam pelbagai bentuk seperti laporan dan artifak.

Walau bagaimanapun, Katz dan Chard (2000) mendefinisikan projek sebagai aktiviti penyiasatan mendalam mengenai sesuatu topik berdasarkan persoalan yang dikemukakan oleh kanak-kanak atau hasil perbincangan mereka dengan pendidik. Aktiviti projek yang dijalankan menerusi Pendekatan Projek ini melibatkan tiga fasa utama iaitu iaitu permulaan projek, perkembangan projek dan kemuncak projek. Kanak-kanak mempunyai peranan utama dalam 
melakukan penyiasatan mendalam secara "real world" manakala guru sebagai fasilitator dan perancang aktiviti projek yang bersesuaian mengikut minat kanak-kanak. Selain itu, kanakkanak terlibat secara aktif dalam aktiviti perbincangan, kajian lapangan, representasi, penyiasatan dan penghasilan artifak untuk dipamerkan dalam atau luar bilik darjah (Helm \& Katz, 2015).

\section{TIGA FASA PELAKSANAAN PENDEKATAN PROJEK}

Setiap penerokaan menerusi Pendekatan Projek dilaksanakan dalam tiga fasa utama. Aktiviti projek bermula dengan persoalan yang dicetuskan oleh kanak-kanak dalam fasa pertama. Semasa fasa pertama, pendidik menggunakan teknik perbincangan untuk mengenal pasti pengalaman dan pengetahuan sedia ada kanak-kanak. Di samping itu, pendidik turut dapat mencungkil minat kanak-kanak terhadap sesuatu topik menerusi pembinaan web kanak-kanak. Malah, segala persoalan kanak-kanak dikumpul dan dicatat oleh pendidik untuk tujuan penerokaan dan penyiasatan kanak-kanak.

Seterusnya, untuk fasa kedua kanak-kanak mendapatkan informasi berkaitan topik yang dipilih untuk diterokai menerusi pelbagai sumber seperti buku, video, gambar dan internet. Seterusnya, kanak-kanak menjalankan aktiviti penyiasatan terhadap persoalan yang telah dikemukakan oleh mereka pada fasa pertama dengan menjalankan kajian lapangan dan bertemu pakar. Pada peringkat ini, pengetahuan kanak-kanak semakin berkembang dengan pengumpulan maklumat yang banyak menerusi khidmat pakar dan perkongsian maklumat dari rakan sebaya yang dipersembahkan dalam pelbagai bentuk lukisan, model, cerita dan lakonan.

Fasa yang terakhir, merupakan aktiviti kemuncak bagi pelaksanaan sesuatu projek. Dalam fasa ini, kanak-kanak membina model atau lakonan berkaitan pembinaan projek yang dipilih untuk dipersembahkan kepada para pelawat pada hari kemuncak projek. Di samping itu, kanak-kanak turut mempersembahkan maklumat yang telah diperolehi sepanjang aktiviti projek bermula dari fasa pertama hingga ketiga (Katz, Chard \& Kogan, 2014).

\section{TUJUAN KAJIAN}

Kajian ini adalah untuk meneroka penyiasatan yang dijalankan secara inisiatif kanak-kanak di sepanjang proses pengajaran dan pembelajaran menerusi Pendekatan Projek. Justeru, kajian ini bertindak menyumbang maklumat berkaitan mengenal pasti elemen-elemen pelaksanaan penyiasatan secara inisiatif kanak-kanak.

\section{METODOLOGI KAJIAN}

Reka bentuk kajian ini menggunakan kajian pelbagai kes (multiple-case design) oleh Yin (2014), bagi meneroka elemen-elemen penyiasatan secara inisiatif yang melibatkan kanakkanak berusia 4+ dan 5+. Kajian pelbagai kes terdiri daripada himpunan kes - kes tunggal yang mempunyai persamaan dari segi ciri-ciri gender, kurikulum dan persekitaran sekolah. Oleh itu, kes-kes tunggal yang terlibat dalam kajian ini melibatkan projek darah dan sabun (Rajah 2). Kes-kes tunggal ini mempunyai persamaan dari segi ciri-ciri (gender), persekitaran (sekolah) dan kategori (standard KSPK). Namun begitu, garisan putus-putus dalam matrik di atas menunjukkan limitasi atau had antara kes dan konteks yang dikaji berkemungkinan hampir sama. Oleh itu, himpunan kes-kes tunggal ini adalah gambaran keseluruhan kajian yang dijalankan (Yin, 2015). 


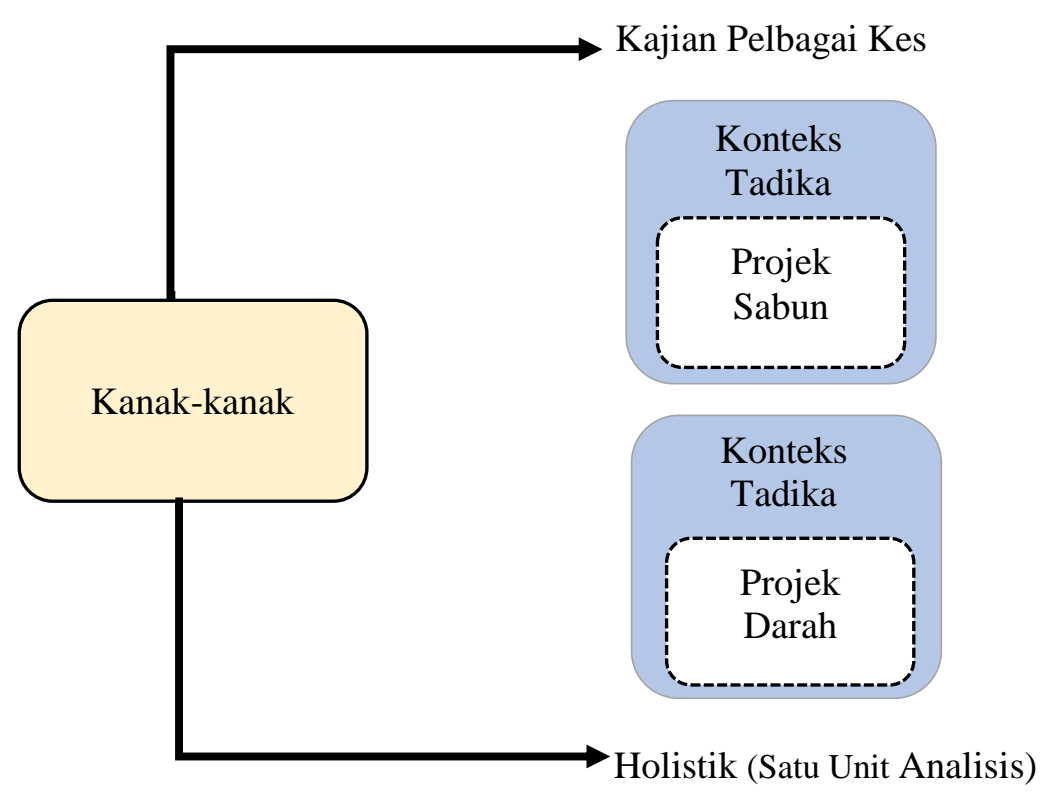

Rajah 2: Kajian pelbagai kes penyiasatan menerusi Pendekatan Projek. Diadaptasi dari Yin (2015).

\section{Pengumpulan data}

Data kajian ini diperoleh daripada dua sumber iaitu dokumen dan pemerhatian:

Pemerhatian yang dijalankan dalam kajian ini bertujuan mendapatkan maklumat berkaitan penyiasatan secara inisiatif yang dijalankan oleh kanak-kanak menerusi Pendekatan Projek. Oleh itu, bagi tujuan merekod pemerhatian, rakaman video terhadap aktiviti yang dijalankan oleh peserta kajian adalah dalam lingkungan masa 30 minit hingga 1 jam iaitu mengikut cadangan peruntukan masa yang dikemukakan oleh Creswell (2014). Penggunaan alat perakam video oleh penyelidik disedari oleh peserta kajian kerana diletakkan di bahagian belakang bilik darjah dan perakam MP3 juga diletakkan di atas meja kanak-kanak. Tempoh rakaman berlangsung selama sepuluh bulan iaitu merangkumi tema tumbuhan sehingga tamat tema alam sekitar. Sehubungan itu, hasil pemerhatian dicatat dalam bentuk tulisan sebagai persediaan untuk menulis laporan (Merriam, 2009). Penyelidik membuat catatan pemerhatian berbentuk "learning stories" yang diadaptasi dari Carr dan Lee (2012) dengan membuat penambahan elemen refleksi mengikut objektif dan signifikan terhadap kajian yang dijalankan.

Dokumen tidak rasmi yang digunakan sebagai sumber data dalam kajian ini adalah berbentuk jurnal dan buku rujukan yang digunakan oleh pendidik, manakala bagi kanak-kanak dokumen yang diguna adalah berbentuk lakaran, buku catatan, model yang dihasilkan serta gambar aktiviti penyiasatan yang relevan dengan kajian ini.

\section{Penganalisisan Data}

Data-data yang diperoleh dianalisis menggunakan kaedah naratif dan analisis kandungan berdasarkan tema, dengan mematuhi tiga proses utama yang dikemukakan oleh Miles dan Huberman (1994) iaitu (1) mereduksikan data, (2) memaparkan data dan (3) membuat kesimpulan serta verifikasi (Rajah 3). 


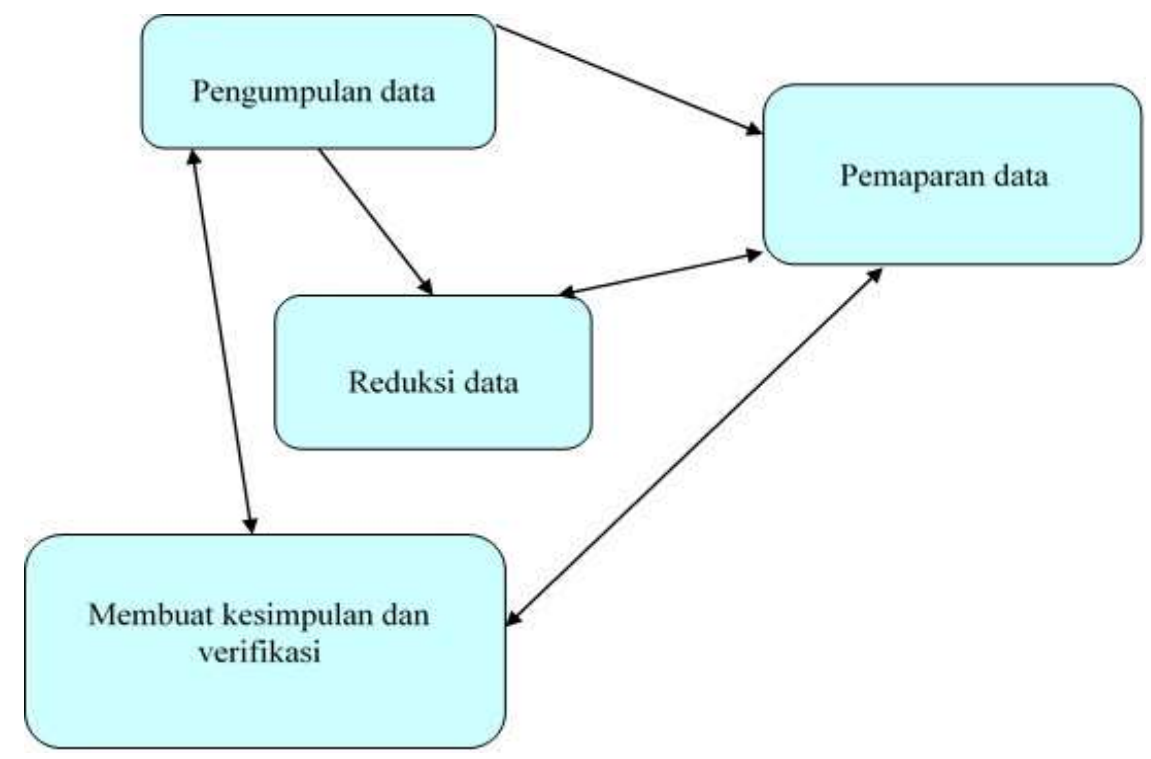

Rajah 3: Analisis data secara interaktif. Diadaptasi daripada Miles dan Huberman (1994).

Penyelidik melakukan penyaringan terhadap data-data yang dikumpul dengan banyaknya dengan meneliti semula semua data yang dikumpul. Selain itu, catatan pemerhatian menerusi rakaman video ditulis semula dalam bentuk "learning story". Fasa kedua, merupakan proses memaparkan data. Pada peringkat ini data-data dipersembahkan secara sistematik menggunakan perkataan, matrik, jadual dan huraian serta peta jaringan. Pada peringkat terakhir, penyelidik membuat kesimpulan bagi menjawab semua persoalan kajian. Bagi menjamin kesahan, kesimpulan yang dibina disokong dengan bukti-bukti dari proses triangulasi data. Malah, bagi memastikan kebolehpercayaan terhadap data adalah tinggi, penyelidik telah mengambil tindakan dengan meneliti hubungan antara data, menyemak kesahan melalui bukti yang menyokong dapatan serta melakukan semakan silang pemahaman dapatan kajian dengan rakan sejawat.

\section{DAPATAN KAJIAN}

Bahagian ini membincangkan dapatan kajian bagi menjawab persoalan "Apakah elemenelemen yang membentuk penyiasatan secara inisiatif kanak-kanak? Bagi mendapatkan data ini, pemerhatian menerusi rakaman video dijalankan di sepanjang proses pengajaran dan pembelajaran berlangsung. Selain itu, data turut diperoleh dalam bentuk dokumen seperti lakaran dan tulisan yang dihasilkan oleh kanak-kanak sebagai sokongan terhadap dapatan data pemerhatian. Dapatan kajian menunjukkan terdapat tiga elemen yang membawa kepada penyiasatan secara inisiatif kanak-kanak iaitu (1) soalan kanak-kanak, (2) pemilihan bahan dan alat radas serta (3) tatacara pelaksanaan penyiasatan dan (4) penghasilan projek.

\section{Soalan kanak-kanak}

Kanak-kanak sentiasa ingin mengetahui sesuatu perkara yang menarik perhatian mereka. Oleh itu, kanak-kanak menyalurkan keinginan mereka dengan mengemukakan pelbagai soalan mengenai sesuatu perkara yang terdapat di persekitaran mereka. Oleh itu, kanak-kanak melalui beberapa siri penerokaan sebelum sesuatu penyiasatan dijalankan bagi memperoleh maklumat mendalam tentang sesuatu topik yang diminati. Sehubungan itu, penyelidik menyenaraikan 
soalan kanak-kanak dan menghuraikannya berdasarkan projek sabun dan projek darah bagi menggambarkan siri penerokaan berdasarkan inisiatif kanak-kanak.

\section{a) Projek Sabun}

Aktiviti penerokaan kanak-kanak Smart bermula pada Februari 2016 sehingga Jun 2016. Data pemerhatian (PE (2) O/RV-15/2/16, perenggan 2) mendapati kanak-kanak mula menunjukkan minat untuk melakukan penyiasatan mengenai strawberi apabila mereka tertarik pada tudung bercorak buah strawberi yang dipakai oleh Cikgu Atul (Gambar Foto 1)

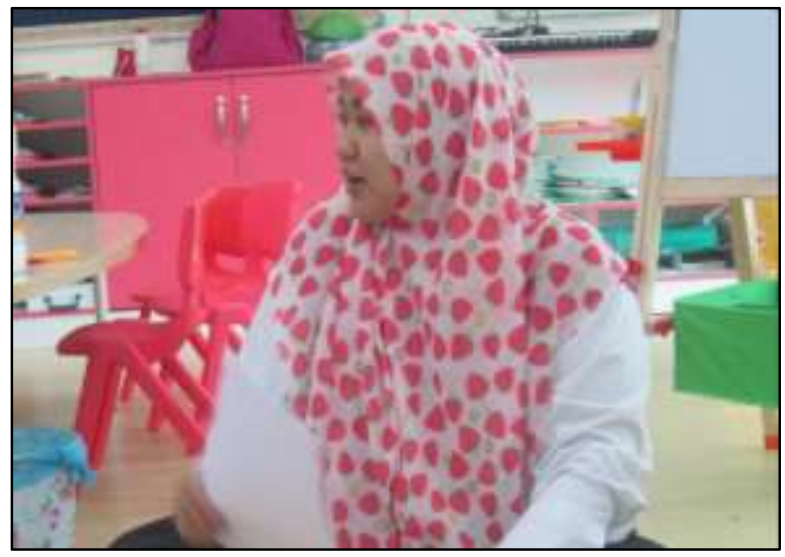

Gambar Foto 1: Corak buah strawberi pada tudung

Data pemerhatian menunjukkan kanak-kanak berpeluang meneroka tentang strawberi apabila mereka keliru dengan rasa buah strawberi. Hal ini dapat dilihat menerusi idea yang dikemukakan oleh kanak-kanak. Menurut Airis, Zaif dan Hanna, "buah strawberi rasa manis", Aqila pula menyatakan bahawa buah strawberi "tak berapa manis" manakala Avelin berpendapat buah strawberi mempunyai "rasa macam masam". Kekeliruan ini menyebabkan kanak-kanak ingin mengetahui "apakah rasa buah strawberi?" (PE (2) O/RV-15/2/16, perenggan 15).

Data pemerhatian menunjukkan kanak-kanak ingin mengetahui dengan lebih lanjut “apakah titik-titik yang ada kat buah strawberi?" (PE (2) O/RV-15/2/16, perenggan 15). Walaupun kanak-kanak dapat menghasilkan lakaran biji (DTR28, 15/2/16) yang terdapat pada buah strawberi tetapi mereka tidak mengetahui tentang fungsi struktur tersebut. Malah, kanakkanak mengenalinya sebagai "titik-titik" ketika berkongsi idea tentang lakaran "my strawberry" (Gambar Foto 2). 

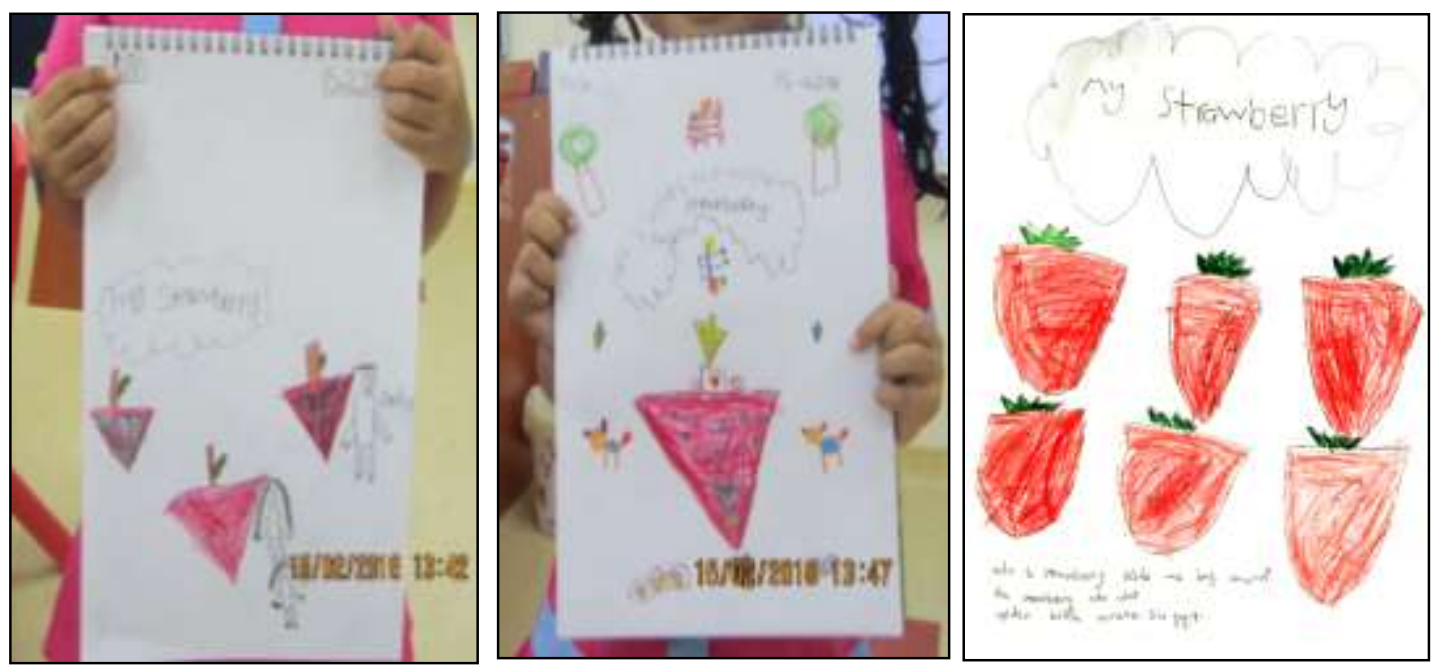

Gambar Foto 2: Kanak-kanak berkongsi cerita tentang "my strawberry"

Di samping itu, data pemerhatian menunjukkan bahawa kanak-kanak juga ingin mengetahui sebab-sebab buah strawberi perlu dibasuh sebelum dimakan. Kanak-kanak berpendapat bahawa buah strawberi adalah bersih dengan memberi alasan bahawa buah tersebut dipetik dari pokok induk dan tidak jatuh ke tanah. Walau bagaimanapun, kanak-kanak kebingungan apabila pendidik menyatakan bahawa buah strawberi perlu dibasuh terlebih dahulu sebelum dimakan oleh mereka. Perkara ini menimbulkan tanda tanya dan perasaan ingin tahu kanak-kanak tentang, "kenapa buah strawberi perlu dibasuh?" (PE (2) O/RV-15/2/16, perenggan 18).

Data pemerhatian (PE (4) O/RV-22/2/16, perenggan 13) mendapati kanak-kanak melakukan penerokaan secara bebas dan penuh bermakna mengenai strawberi pada 22 Februari 2016 ketika melakukan kerja lapangan di ladang strawberi, Mini Cameron Highland. Semasa melakukan penyiasatan di barisan batas semaian strawberi, kanak-kanak ternampak buah strawberi yang rosak. Pada buah strawberi tersebut kelihatan biji-biji halus yang banyak. Oleh itu, pendidik menjelaskan bahawa yang diperhatikan tersebut adalah biji benih. Walau bagaimanapun, kanak-kanak kurang faham tentang istilah "biji benih" yang dinyatakan oleh pendidik. Lalu kanak-kanak mengemukakan soalan, "cikgu, biji benih tu apa? (PE (4) O/RV$22 / 2 / 16$, perenggan 15), ingin mengetahui dengan lebih lanjut tentang perkara yang diperhatikan tersebut (Gambar Foto 3)
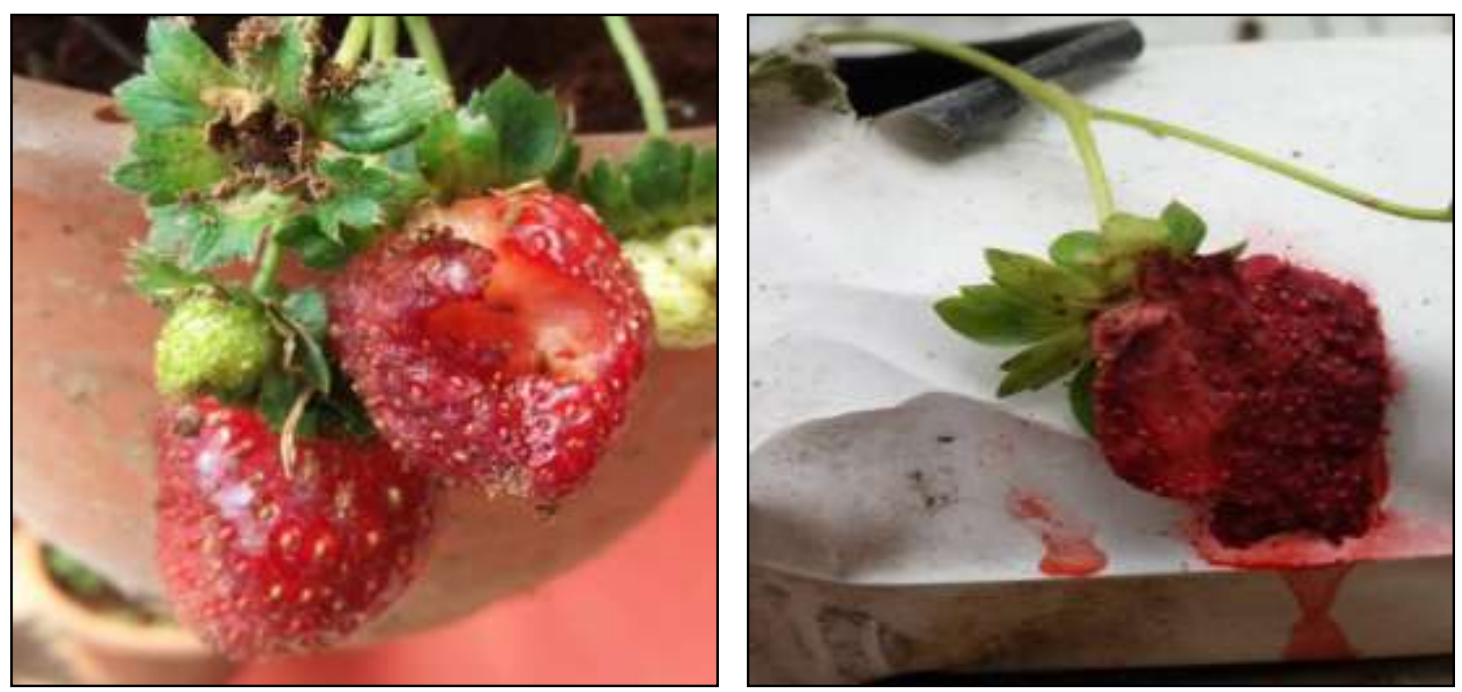

Gambar Foto 3: Struktur biji-biji halus pada buah strawberi yang diperhatikan oleh kanak-kanak 
Data pemerhatian mendapati kanak-kanak turut ingin mengetahui bagaimana roti yang digunakan semasa penyiasatan pertumbuhan kulat telah dihasilkan. Kanak-kanak menyatakan kepada pendidik bahawa roti merupakan kegemaran mereka kerana rasanya yang sedap dan manis. Selain itu, kanak-kanak juga berkongsi idea bahawa terdapat pelbagai bentuk roti yang pernah dilihat dan dibeli di kedai kek. Oleh itu, kanak-kanak menunjukkan bahawa mereka berminat untuk membuat roti dengan mengemukakan soalan kepada pendidik, "cikgu macam mana nak buat roti?"' (PE (6) O/RV-2/3/16, perenggan 6).

Selain itu, kanak-kanak juga ingin mengetahui tentang yis yang digunakan sebagai salah satu bahan asas di samping gula, tepung gandum, marjerin dan air suam yang digunakan untuk membuat roti. Pengalaman pertama kali melihat serbuk yis, menimbulkan tanda tanya kepada kanak-kanak "yis ni apa, cikgu?" Malah, kanak-kanak terperanjat apabila mendapati larutan campuran antara yis, gula dan air suam telah menghasilkan larutan berbuih yang mengembang naik serta menghasilkan bau yang kurang menyenangkan. Oleh itu, kanak-kanak mengemukakan soalan, "kenapa dia naik nie cikgu? dan "kenapa ada bau busuk? (PE (7) O/RV-3/3/16, perenggan 16) (Gambar Foto 4). Selain itu, kanak-kanak juga ingin mengetahui "kenapa dia jadi besar" apabila melihat perubahan saiz asal adunan setelah dibiarkan seketika. Kanak-kanak juga kehairan apabila melihat perkara yang sama turut berlaku apabila roti menjadi lebih besar berbanding saiz asal setelah dimasukkan ke dalam oven (PE (7) O/RV$3 / 3 / 16$, perenggan 22 ).
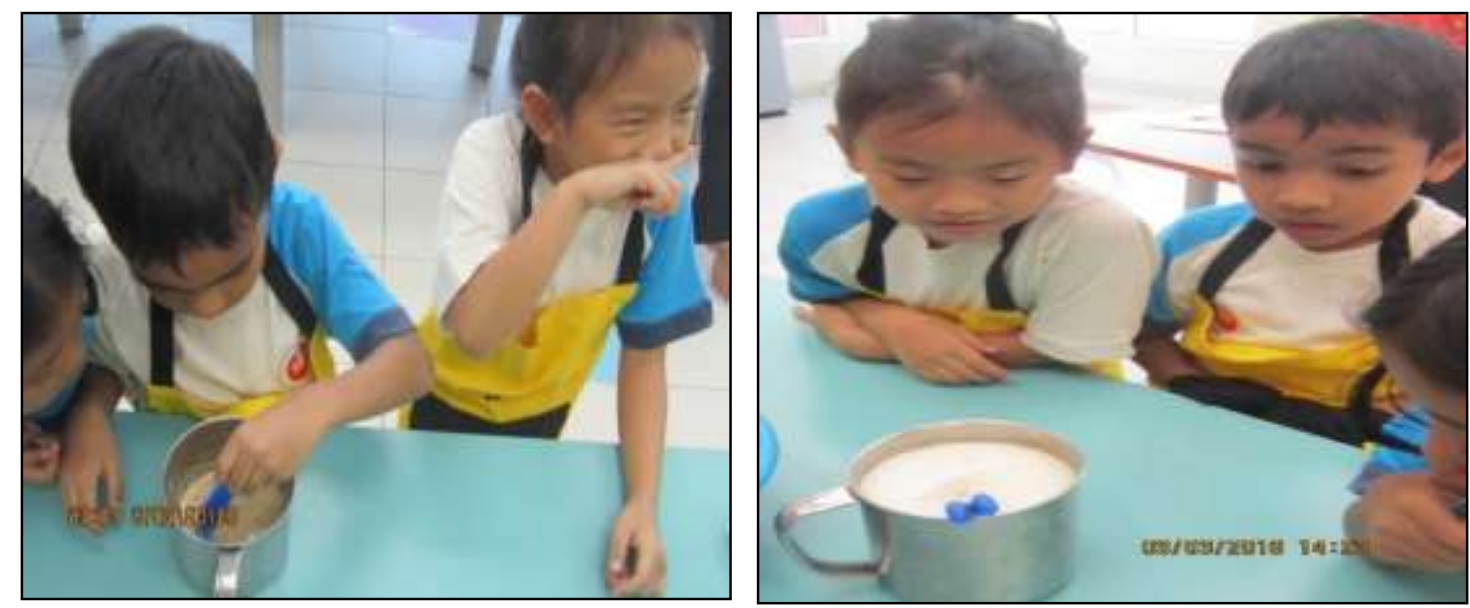

Gambar Foto 4: Kanak-kanak terperanjat melihat larutan mengembang dan berbau busuk

\section{b) Projek Darah}

Kanak-kanak Proaktif melakukan penerokaan bagi tema alam sekitar bermula pada Jun 2016 sehingga September 2016. Aktiviti penerokaan kanak-kanak bermula dengan aktiviti kerja lapangan di Zoo Negara. Data pemerhatian (PF (13) O/RV-26/5/16, perenggan 2) mendapati kanak-kanak berusaha membaca peta lokasi yang mempamerkan maklumat berkaitan jenisjenis haiwan yang terdapat dalam kawasan tersebut (Gambar Foto 5). 


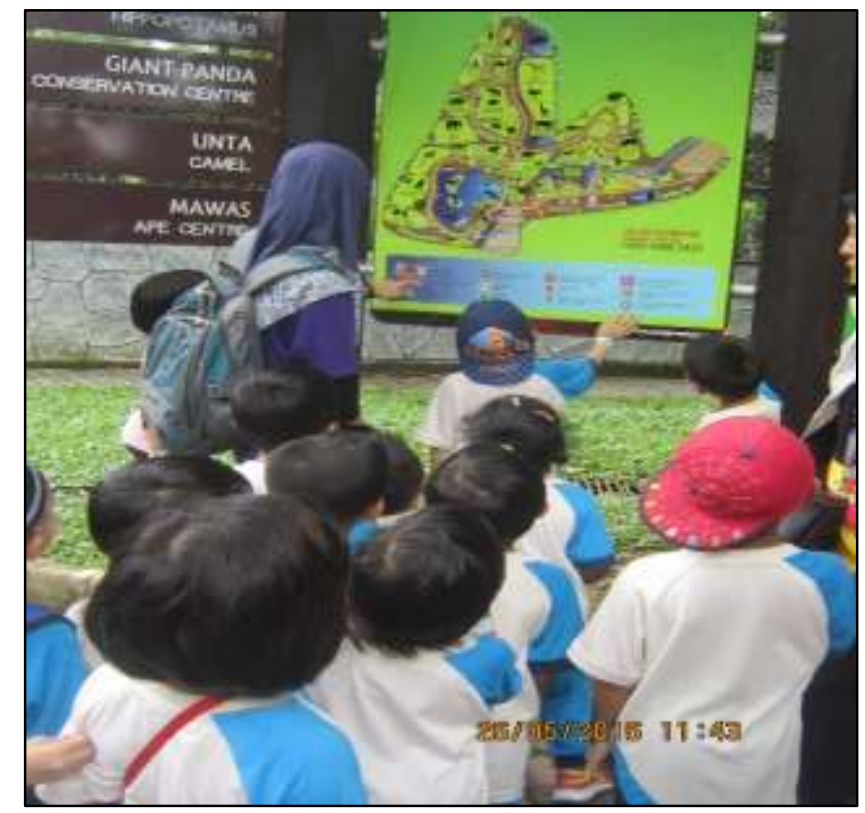

Gambar Foto 5: Kanak-kanak membaca maklumat yang terdapat pada peta lokasi Zoo Negara.

Oleh itu, kanak-kanak bergerak secara bebas bersama ibu bapa (Gambar Foto 6) untuk mendapatkan informasi berkaitan haiwan dengan membuat lakaran, membaca serta menulis maklumat yang dipamerkan dalam lokasi tersebut (PF (13) O/RV-26/5/16, perenggan 5).
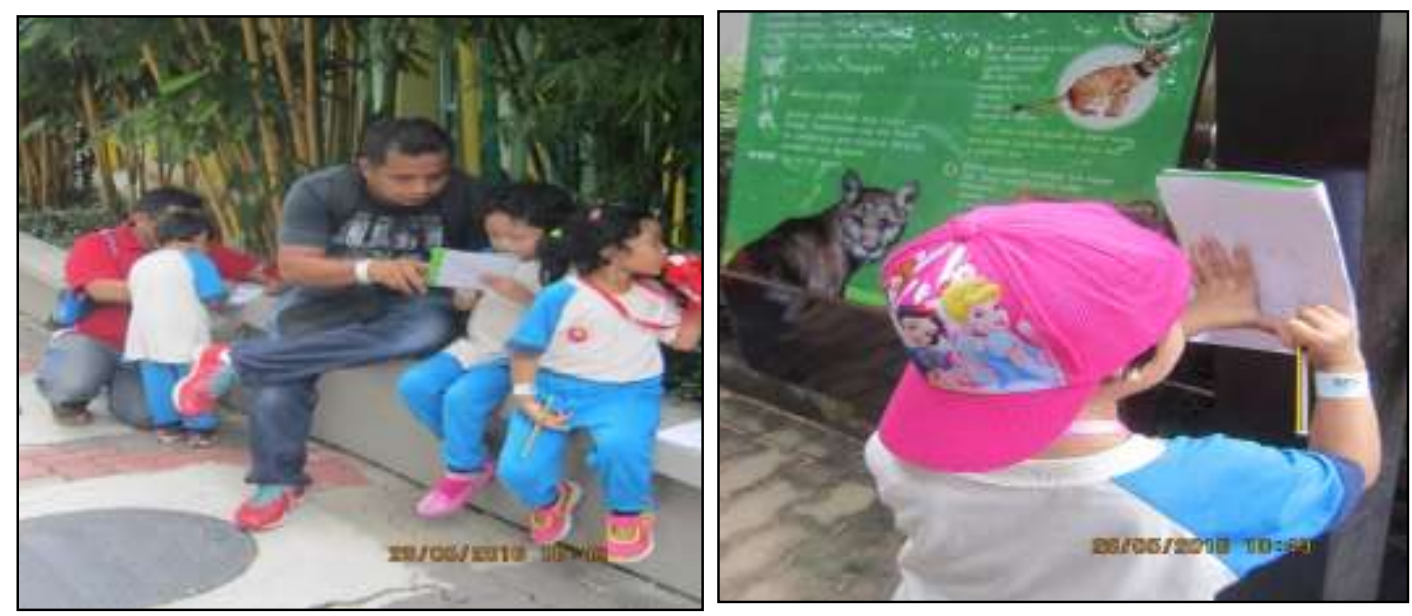

Gambar Foto 6: Kanak-kanak mencatat pelbagai maklumat tentang haiwan di Zoo Negara.

Pelbagai maklumat yang diperoleh oleh kanak-kanak tentang haiwan-haiwan yang terdapat di Zoo Negara. Namun, kanak-kanak menunjukkan minat mendalam terhadap haiwan herbivor koala. Hal ini dapat diperhatikan apabila lebih daripada separuh kanak-kanak yang melakarkan koala. Selain itu, kanak-kanak turut berkeupayaan berkongsi idea mengenai haiwan tersebut, antaranya berkaitan struktur fizikal, tabiat pemakanan dan asal usul koala yang ditempatkan di Zoo Negara (PF (1) O/RV-21/6/16, perenggan 6).

Walau bagaimanapun, muncul kekeliruan mengenai jenis pembiakan koala. Data pemerhatian mendapati lebih daripada sebahagian kanak-kanak beranggapan bahawa koala membiak secara bertelur berbanding beranak. Oleh itu, kanak-kanak berhujah sesama sendiri untuk mempertahan idea masing-masing. Untuk mengatasi masalah tersebut, kanak-kanak 
meminta pendidik untuk mencari maklumat menerusi enjin carian google untuk mendapatkan jawapan tersebut, “cikgu, boleh tak kita google nak tengok koala?" (PF (1) O/RV-21/6/16, perenggan 8).

Data pemerhatian turut mendapati bahawa kanak-kanak berminat untuk melihat struktur tulang haiwan. Keinginan kanak-kanak untuk melakukan penerokaan tercetus ketika sesi perbincangan mengenai cara-cara haiwan bergerak. Kanak-kanak berjaya mendemonstrasikan cara-cara haiwan bergerak seperti berlari seperti kuda, berjalan perlahan seperti kura-kura dan membongkok seperti koala. Walau bagaimanapun setelah aktiviti tersebut berlangsung, kanak-kanak mula mempersoalkan "kenapa binatang boleh bergerak?"

Sehubungan itu, kanak-kanak dibimbing oleh pendidik untuk mengenal pasti struktur tulang yang terdapat pada anggota badan mereka Kanak-kanak kelihatan seronok melakukan aktiviti menyentuh anggota badan rakan untuk mengenal pasti bentuk dan struktur tulang yang keras (PF (1) O/RV-21/6/16, perenggan 9).

Data pemerhatian mendapati perasaan ingin tahu kanak-kanak semakin mendalam untuk melihat struktur tulang serta menyelidiki komposisi tulang dengan mengemukakan soalan kepada pendidik, "boleh tak kita tengok tulang, cikgu?" (PF (1) O/RV-21/6/16, perenggan 10). Selain itu, kanak-kanak juga berminat untuk mengetahui "apa yang ada dalam tulang?" (PF (1)O/RV-21/6/16, perenggan 10)

Selain itu, kanak-kanak juga berminat untuk mengetahui tentang penghasilan darah yang terdapat dalam tulang ayam. Situasi ini berlaku ketika kanak-kanak melihat darah mengalir keluar daripada tulang yang dipotong oleh pendidik. Oleh itu, kanak-kanak tertarik untuk mengetahui “darah ni dari mana?” (PF (6) O/RV-14/7/16, perenggan 3).

\section{Pemilihan bahan dan alat radas}

Penyelidik mendapati kanak-kanak menggunakan daya inisiatif mereka sendiri untuk menentukan cara menjalankan sesuatu penyiasatan. Perkara ini dapat diperhatikan menerusi peluang yang diberikan oleh pendidik kepada kanak-kanak dalam mengemukakan idea tentang pemilihan penggunaan bahan dan alat radas.

Data pemerhatian mendapati penggunaan alat radas dan bahan yang digunakan dalam sesuatu aktiviti penyiasatan adalah berdasarkan cadangan kanak-kanak. Pendidik berfungsi sebagai perancah dalam menyediakan sumber untuk memenuhi keperluan kanak-kanak. Contohnya, kanak-kanak Smart telah mencadangkan penggunaan bahan-bahan seperti buah strawberi dan roti manakala pinggan sebagai alat radas yang turut digunakan dalam penyiasatan berkaitan pertumbuhan kulat (PE (5) O/RV-1/3/16, perenggan 8). Malah, terbukti bahawa pada hari penyiasatan dijalankan ( $\mathrm{PE}(6) \mathrm{O} / \mathrm{RV}-2 / 3 / 16$, perenggan 7), pendidik telah menyediakan bahan-bahan seperti yang telah disenaraikan oleh kanak-kanak (DTRA 20, 2/3/16) (Gambar Foto 7). 


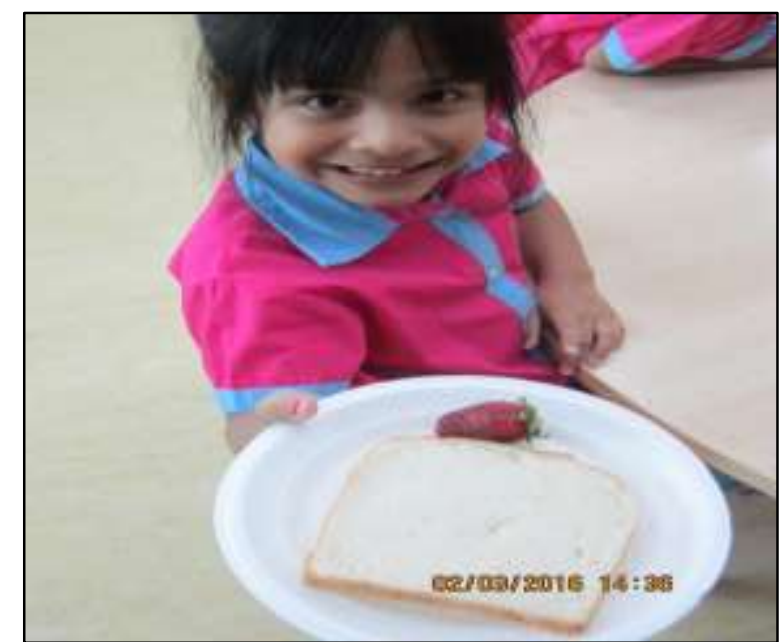

Gambar Foto 7: Bahan-bahan yang digunakan untuk menyiasat pertumbuhan kulat

Selain itu, kanak-kanak Proaktif juga berperanan aktif dalam mengemukakan idea mengenai penggunaan sumber bahan yang diperlukan dalam penyiasatan berkaitan tulang. Kanak-kanak membuat pertimbangan yang wajar ketika membuat pemilihan terhadap jenisjenis haiwan yang akan digunakan dalam penyiasatan mereka. Misalnya, kanak-kanak membuat keputusan untuk menggunakan ayam sebagai bahan ujikaji yang memudahkan mereka untuk melihat struktur tulang ( $\mathrm{PF}$ (4) O/RV-28/6/16, perenggan 15). Oleh itu, data pemerhatian mendapati (PF (6) O/RV-14/7/16, perenggan 1).pendidik telah membawa seekor ayam yang mempunyai struktur fizikal yang lengkap untuk dijadikan bahan ujikaji kanakkanak (DTRA21, 14/7/16) (Gambar Foto 8).

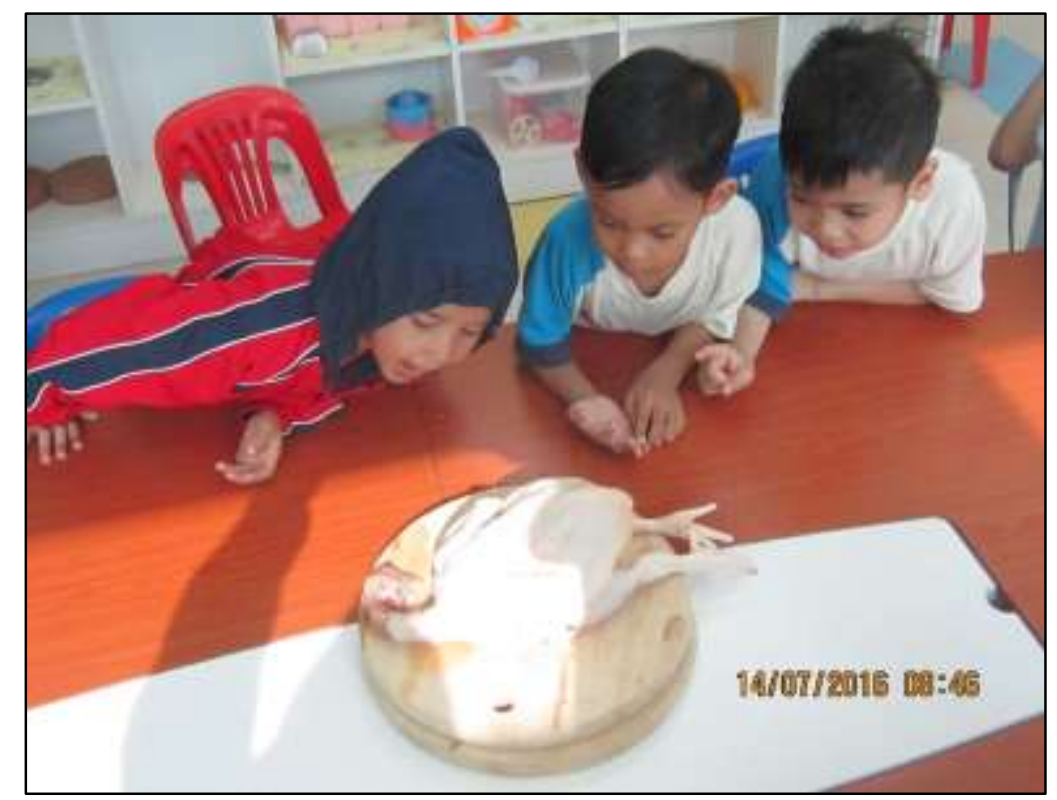

Gambar Foto 8: Ayam yang digunakan dalam penyiasatan berkaitan tulang

\section{Tatacara pelaksanaan penyiasatan}

Data pemerhatian menunjukkan bahawa tatacara pelaksanaan sesuatu penyiasatan juga melibatkan cetusan idea daripada kanak-kanak. Sebelum melakukan sesuatu penyiasatan, kanak-kanak bersama pendidik melakukan perbincangan mengenai langkah-langkah yang perlu diberi perhatian dalam melaksanakan sesuatu penyiasatan. 
Selain itu, data pemerhatian (PE (8) O/RV-7/3/16, perenggan 6) mendapati kanakkanak Smart juga turut mengemukakan idea mengenai langkah-langkah dalam melaksanakan penyiasatan tentang pertumbuhan kulat pada pelbagai jenis bahan makanan. Antara bahan makanan yang menjadi pilihan kanak-kanak dalam ujikaji ini adalah terdiri daripada buahbuahan, kek, nasi dan biskut.

Kanak-kanak turut memberi justifikasi terhadap pemilihan bahan seperti plastik yang turut digunakan dalam penyiasatan tersebut. Kanak-kanak menjelaskan bahawa plastik digunakan sebagai alat pembungkusan sampel makanan tersebut agar tidak terdedah kepada bahan cemar yang terdapat dalam udara. Di samping itu, tempoh pelaksanaan pemerhatian terhadap sampel makanan tersebut turut dicadangkan oleh kanak-kanak kepada pendidik. Kanak-kanak menyatakan bahawa pemerhatian terhadap kehadiran kulat akan dijalankan pada setiap hari dan direkodkan dalam buku jurnal mereka (PE (8) O/RV-7/3/16, perenggan 9).

Oleh itu, data pemerhatian (PE (12) O/RV-19/4/16, perenggan 2) mendapati pelaksanaan penyiasatan sebenar adalah seperti yang dirancangkan iaitu semua sampel makanan dimasukkan ke dalam plastik yang kemudiannya ditutup rapi agar tidak terdedah kepada habuk dan udara (Gambar Foto 9). Kemudian, bahan-bahan tersebut diletakkan di atas meja yang dalam bilik darjah. Akhirnya, kanak-kanak melakukan pemerhatian dan merekod pertumbuhan kulat yang terdapat pada sampel makanan mengikut jumlah hari yang telah ditetapkan (Gambar Foto 10).
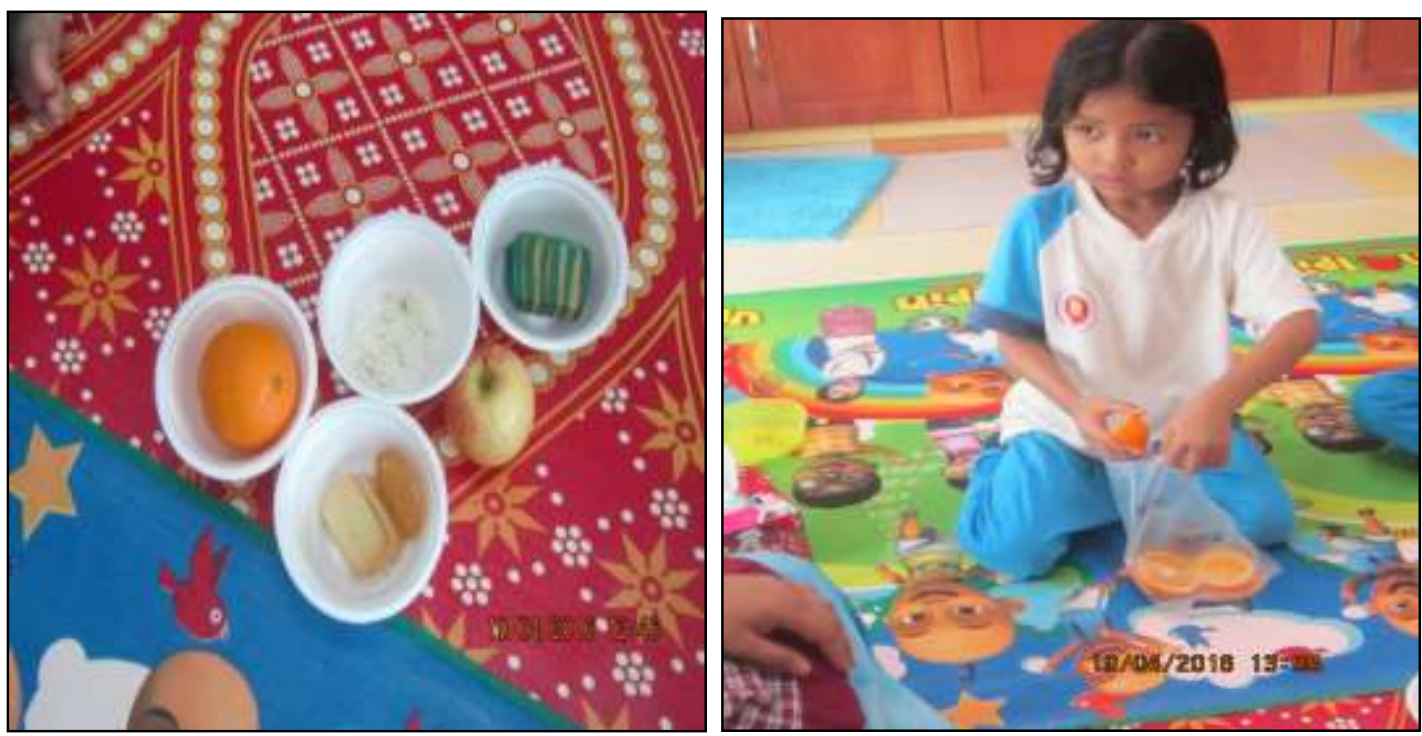

Gambar Foto 9: Kanak-kanak memasukkan bahan makanan ke dalam plastik 

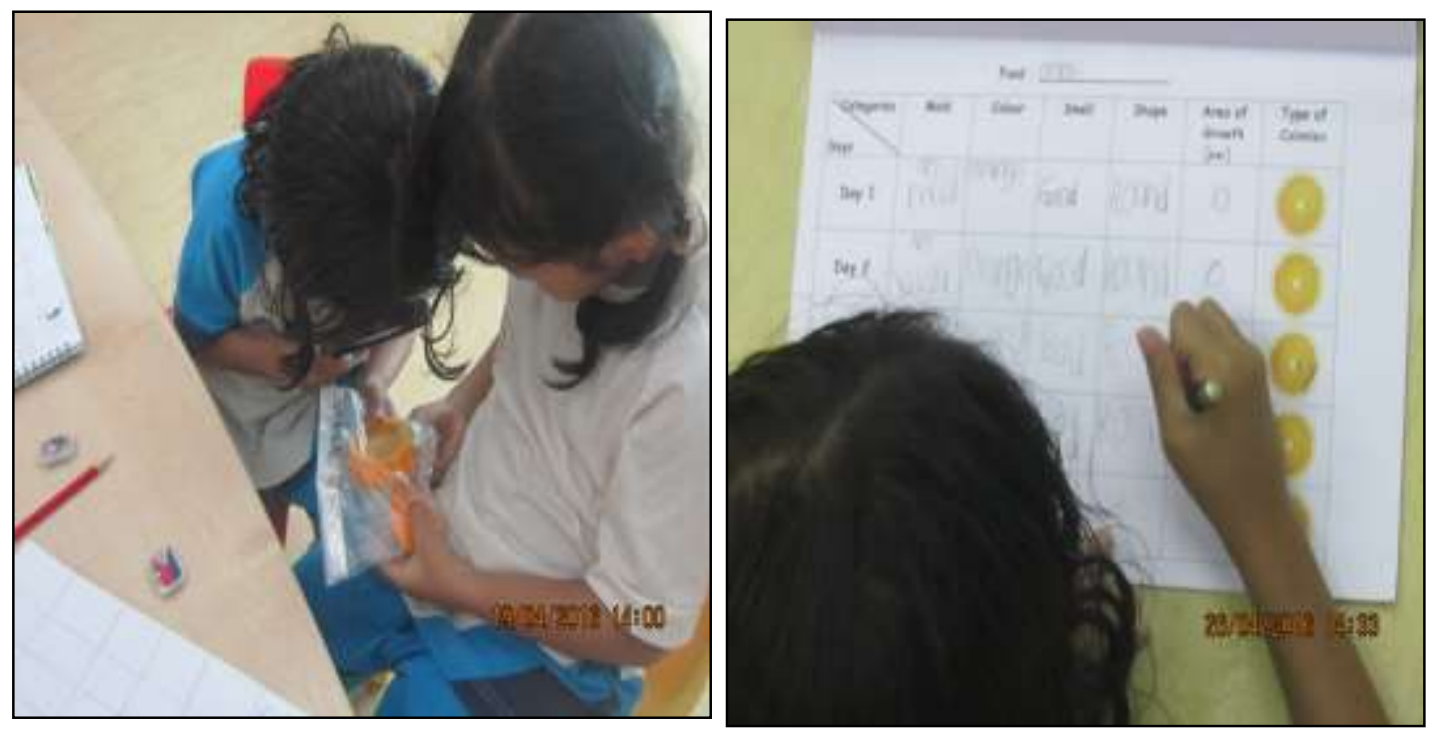

Gambar Foto 10: Kanak-kanak melakukan pemerhatian dan merekod pertumbuhan kulat

\section{Penghasilan Projek}

Data pemerhatian mendapati projek yang dihasilkan oleh kanak-kanak adalah berdasarkan idea mereka sendiri. Contohnya, projek sabun dihasilkan oleh kanak-kanak Smart setelah mereka memperoleh idea daripada aktiviti bertemu pakar (PE (18) O/RV-10/5/16, perenggan 6).

Aktiviti bersama pakar melibatkan pembuatan sabun dengan menggunakan bahanbahan organik seperti "white soap base", "transparent soap base" dan pewarna makanan bagi menghasilkan kombinasi warna sabun yang menarik (DTRA35, 10/5/16). Menerusi pengalaman membuat sabun menggunakan kaedah "double boil", kanak-kanak berminat dan mengemukakan idea untuk mempamerkan koleksi sabun yang telah dibuat oleh mereka sendiri sebagai projek akhir (Gambar Foto 11).
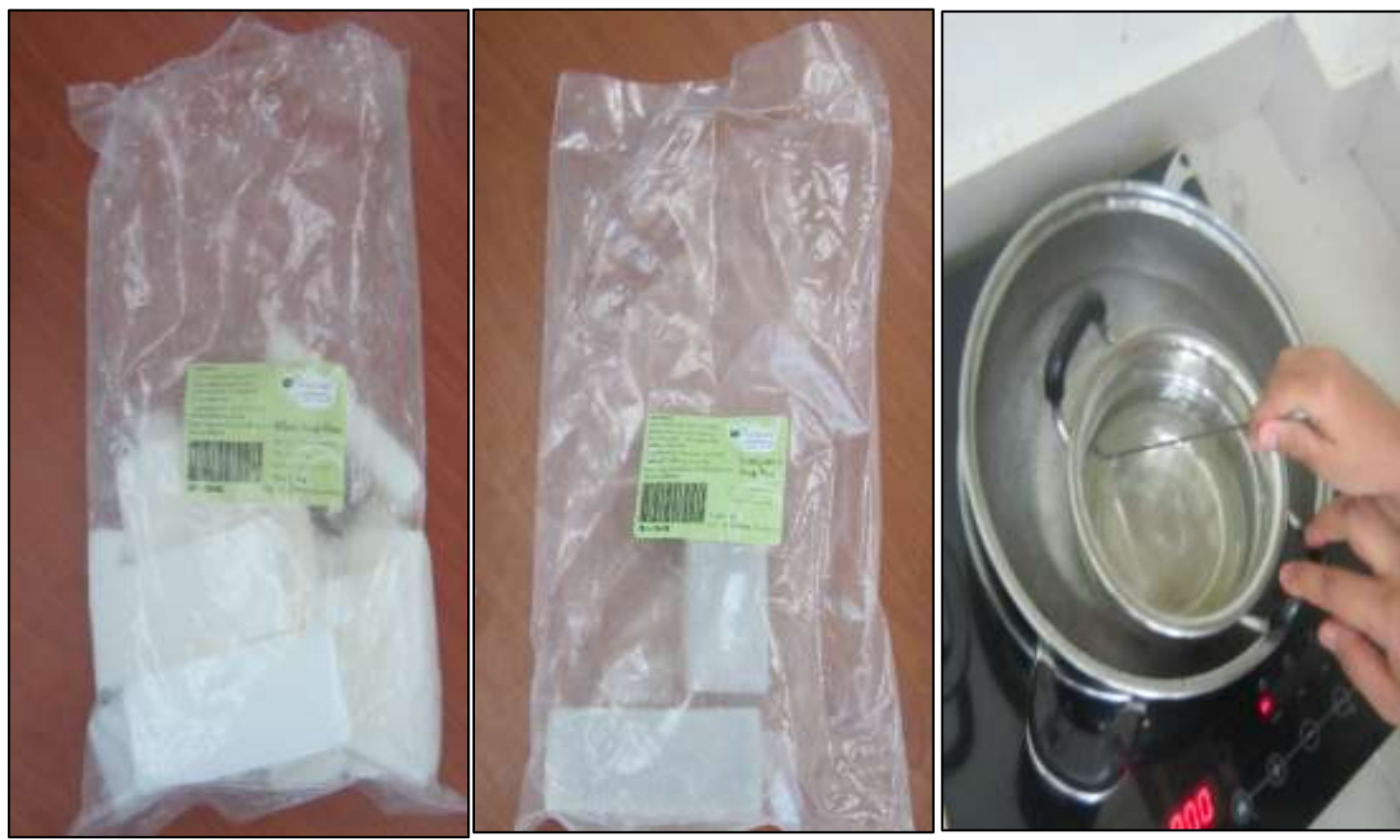

Gambar Foto 11: Bahan-bahan asas dalam penghasilan sabun menerusi kaedah "double boil" 
Manakala data pemerhatian (PF (16) O/RV-29/8/16, perenggan 3) mendapati kanakkanak Proaktif mencadangkan kepada pendidik untuk menghasilkan model peredaran darah sebagai projek akhir mereka. Idea ini diperoleh apabila kanak-kanak tertarik sistem peredaran darah yang ditunjukkan oleh pakar yang merupakan seorang pegawai perubatan (PF (15) O/RV-16/8/16, perenggan 6).

Sehubungan itu, elemen-elemen yang terdapat pada sistem peredaran darah manusia ini juga adalah berdasarkan idea yang dikemukakan oleh kanak-kanak sendiri. Contohnya, kanakkanak mencadangkan kepada pendidik untuk menghasilkan darah dengan menggunakan campuran air dan pewarna minuman yang berwarna merah manakala salur darah dicipta menggunakan tiub getah dan jantung dibina menggunakan botol mineral.

Sehubungan itu juga, kanak-kanak turut mencadangkan agar model badan manusia dibina menggunakan kotak (PF (16) O/RV-29/8/16, perenggan 5). Walau bagaimanapun, kanak-kanak mendapati bahawa kotak yang diperbuat daripada kertas mudah basah dan terkoyak apabila terkena sesuatu cecair seperti darah yang akan digunakan dalam projek mereka. Oleh itu, akhirnya kanak-kanak mencadangkan agar plastik digunakan sebagai bahan asas untuk binaan model badan manusia (PF (16) O/RV-29/8/16, perenggan 7).

Selain itu, data pemerhatian ( $\mathrm{PF}$ (17) O/RV-1/9/16, perenggan 7) mendapati kanakkanak turut mengambil inisiatif untuk menguji model yang dihasilkan untuk memastikan ianya dapat berfungsi dengan baik pada hari pameran kemuncak (Gambar Foto 12). Situasi ini dapat dilihat apabila kanak-kanak Proaktif membina dan menguji model peredaran darah yang akan digunakan pada hari pameran tersebut (DTRA 42, 1/9/16).

Selain itu, data pemerhatian mendapati kanak-kanak turut menyumbangkan idea untuk menghasilkan sesuatu produk mengikut reka bentuk mereka sendiri. Hal ini dapat dilihat menerusi penghasilan sabun oleh kanak-kanak adalah berdasarkan idea mereka yang dijelaskan menerusi lakaran awal "my soap" (DTR45, 6/5/16). Lakaran ini memaparkan bentuk, warna, jenis pewangi dan dan bahan-bahan yang akan digunakan oleh kanak-kanak untuk menghias sabun mereka (Rajah 4.30). Antara bentuk yang menjadi pilihan kanak-kanak ialah daun, beruang, katak dan itik. Sementara itu, kanak-kanak memilih untuk menggunakan duit syiling, bunga kering dan "google eye" sebagai hiasan sabun yang akan dihasilkan oleh mereka (PE (17) $\mathrm{O} / \mathrm{RV}-6 / 5 / 16$, perenggan 5). 

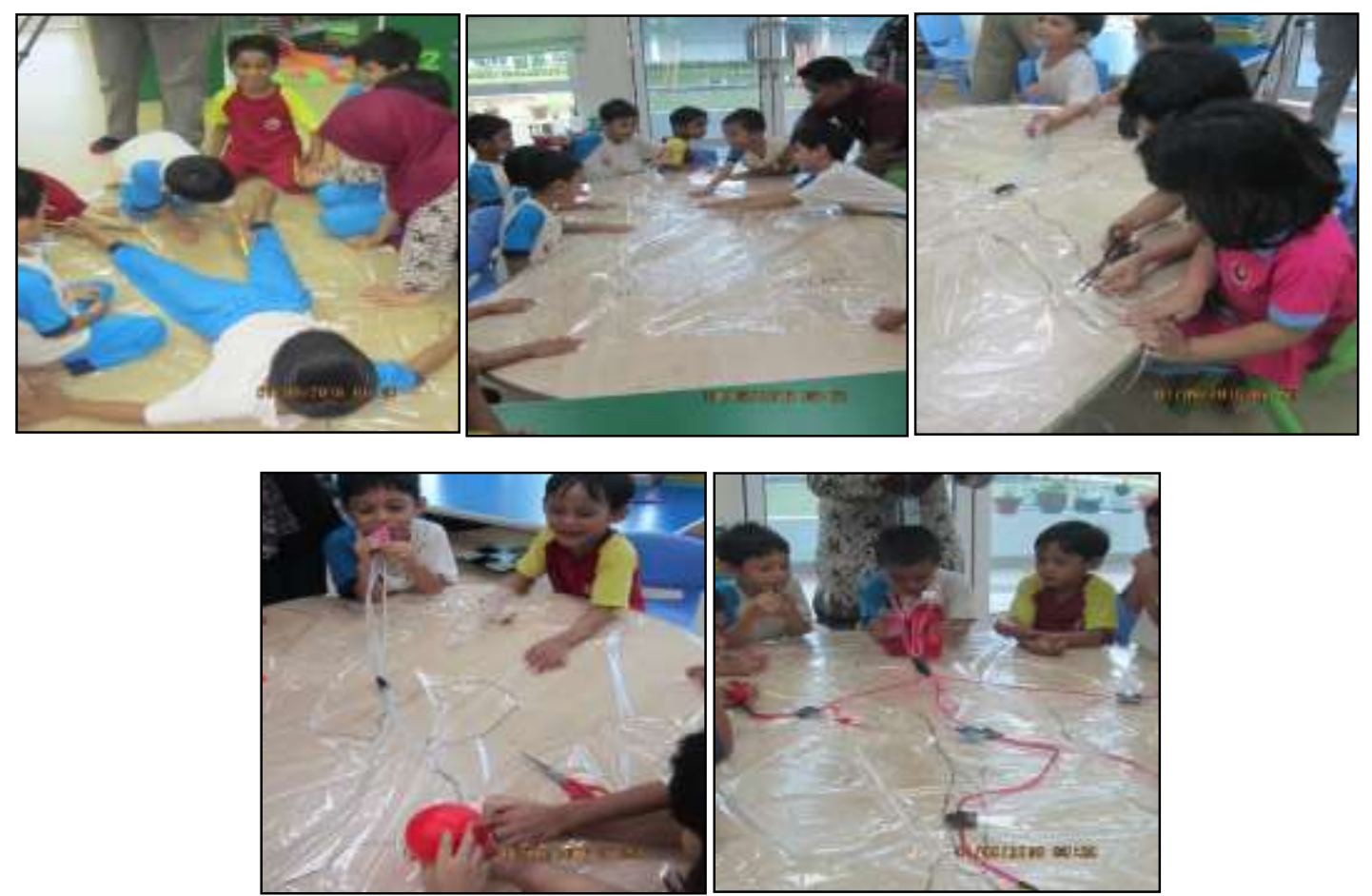

Gambar Foto 12: Kanak-kanak membina dan menguji model peredaran darah

Kanak-kanak Smart juga telah menyenaraikan jumlah sabun yang akan dihasilkan (Rajah 4.30b). Contohnya, Avelin menulis bahawa dua buah sabun berbentuk daun yang mempunyai kombinasi warna kuning dan oren akan dihasilkannya sebanyak dua ketul. Sementara itu, Aqila juga turut merancang untuk menghasilkan jumlah sabun berbeza mengikut bentuk. Contohnya, sabun berbentuk beruang sebanyak dua ketul, bentuk itik sebanyak tujuh ketul dan katak sejumlah enam ketul. Selain itu, Aqila juga telah menetapkan bahawa wangian jenis lemon digunakan dalam sabun yang akan dihasilkannya (PE (17) O/RV6/5/16, perenggan 6).
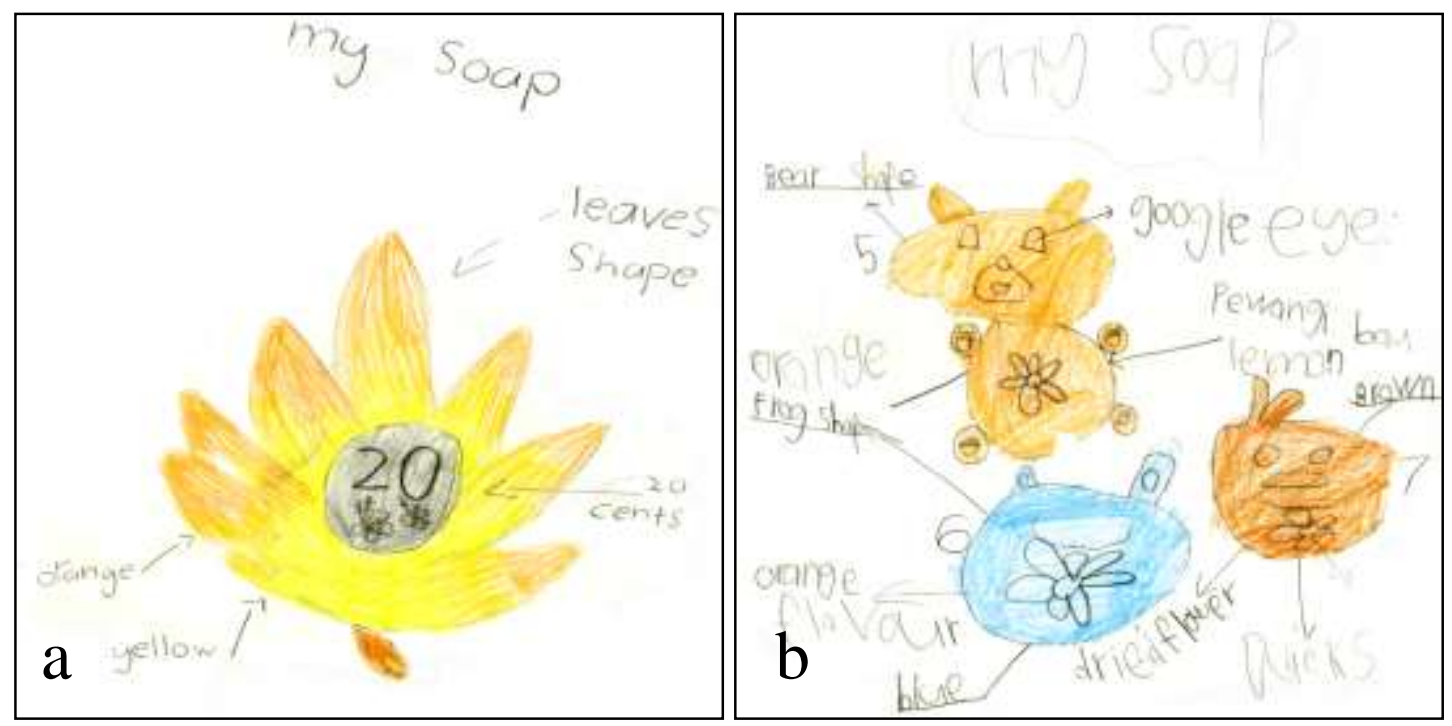

Rajah 4.30: (a)Lakaran awal kanak-kanak tentang bentuk, warna, jenis pewangi, bahan hiasan dan (b) jumlah sabun yang akan dihasilkan. 
Sehubungan itu, data pemerhatian turut menunjukkan bahawa kanak-kanak juga terlibat dalam menentukan tetamu yang akan dijemput pada hari pameran perdana bagi projek mereka. Contohnya, kanak-kanak Smart menetapkan bahawa guru-guru taska, tadika dan pembantu pembimbing murid akan dijemput sebagai tetamu jemputan dan diberikan cenderahati (PE (20) O/RV-20/5/16, perenggan 2).

Selain itu, kanak-kanak juga bertindak merancang susun atur bahan pameran (PE (20) O/RV-20/5/16, perenggan 4). Contohnya, kanak-kanak bersepakat membuat keputusan untuk meletakkan sabun-sabun di atas meja sedia ada dengan cara penyusunan meja secara memanjang (DTRA35, 23/5/16).

Sementara itu, kanak-kanak turut terlibat dalam melantik pakar informasi dalam kalangan rakan mereka yang bertanggungjawab mempersembahkan projek dan menerangkan proses pembelajaran yang telah dilalui oleh mereka. Walau bagaimanapun, kanak-kanak Smart memutuskan bahawa mereka akan terlibat sebagai pakar informasi. Hal ini berikutan daripada semua kanak-kanak Smart secara sukarela ingin menjadi pakar informasi pada hari pameran perdana (PE (20) O/RV-20/5/16, perenggan 5).

Justeru, data pemerhatian (PE (19) O/RV-11/5/16, perenggan 1) mendapati kanakkanak telah menghasilkan sabun untuk dipamerkan pada hari pameran perdana (Gambar Foto 13). Oleh itu, pada hari pameran (PE (21) O/RV-23/5/16, perenggan 2) diadakan didapati sabun-sabun yang dihasilkan adalah sama seperti yang diingini oleh kanak-kanak (Gambar Foto 14). Bahan-Bahan pameran juga telah disusun dengan teratur di atas meja (Gambar Foto 15). Sehubungan itu, kanak-kanak bertindak memberikan informasi yang tepat kepada tetamu hadir mengenai proses pembelajaran yang telah dilalui oleh mereka (Gambar Foto 16). Malahan, tetamu yang hadir juga berpeluang menguji sampel sabun yang telah dihasilkan oleh kanak-kanak dengan cara membasuh tangan dan menghidu aroma yang terdapat pada sabun tersebut (Gambar Foto 17).
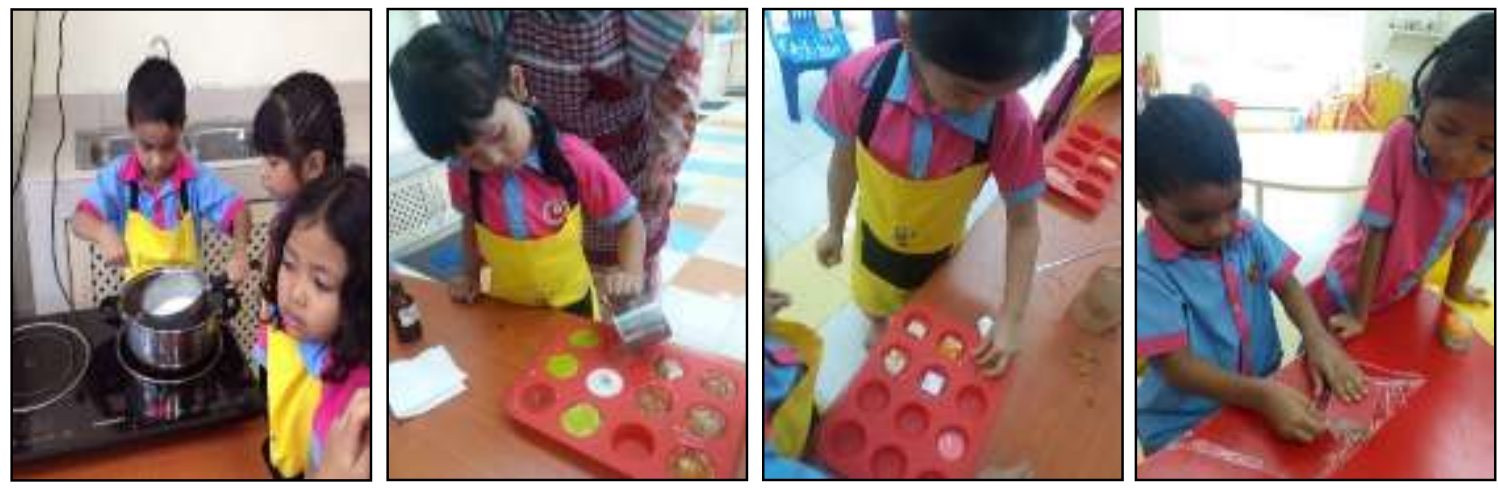

Gambar Foto 13: Proses pembuatan sabun oleh kanak-kanak 


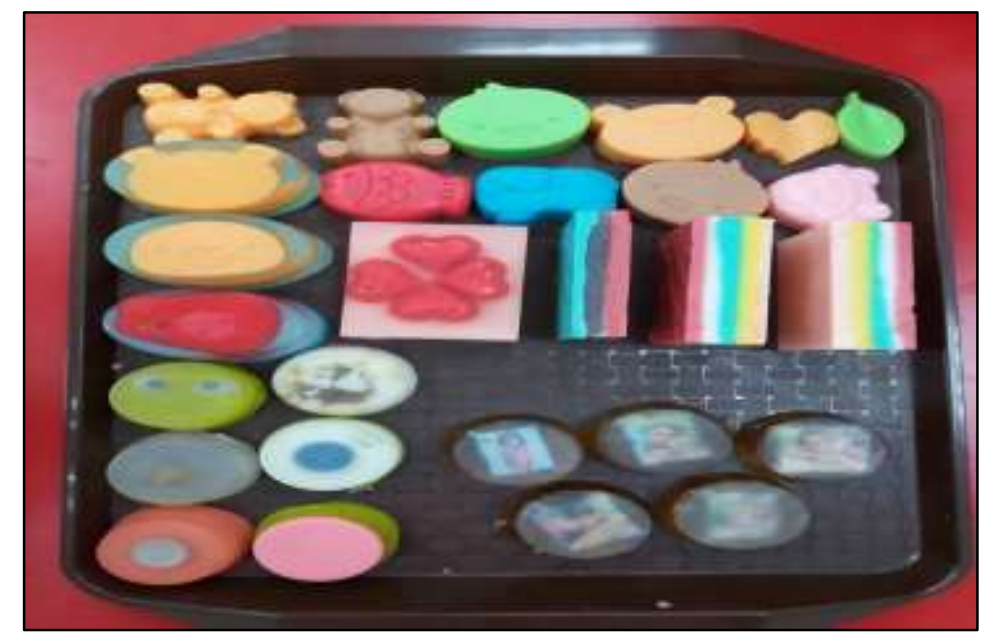

Gambar Foto 14: Koleksi sabun yang dihasilkan adalah sama seperti lakaran awal kanak-kanak
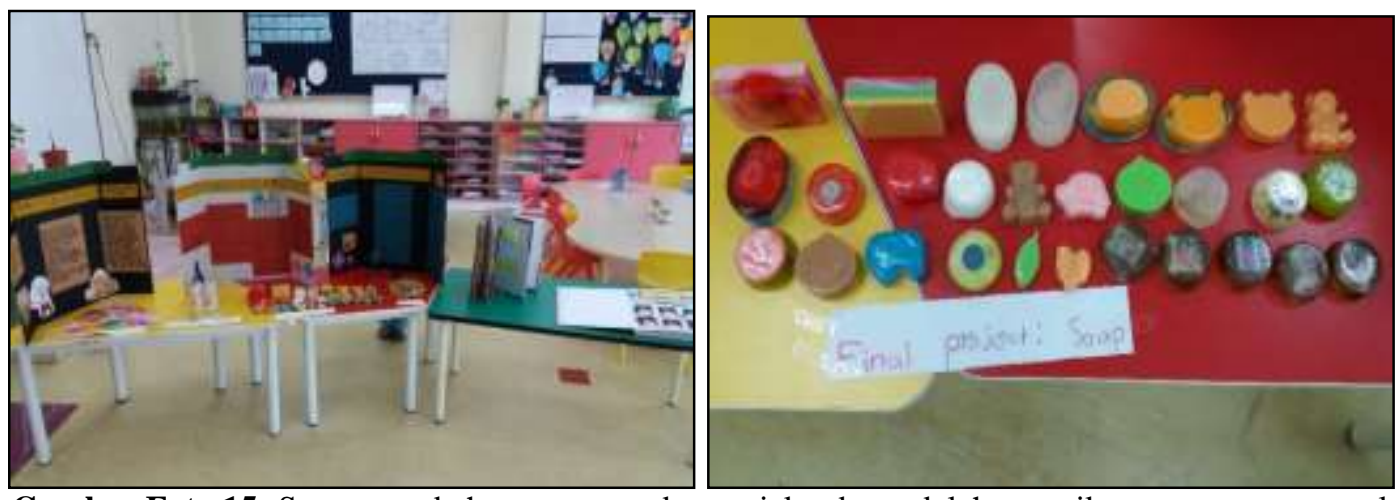

Gambar Foto 15: Susun atur bahan pameran dan projek sabun adalah mengikut perancangan awal
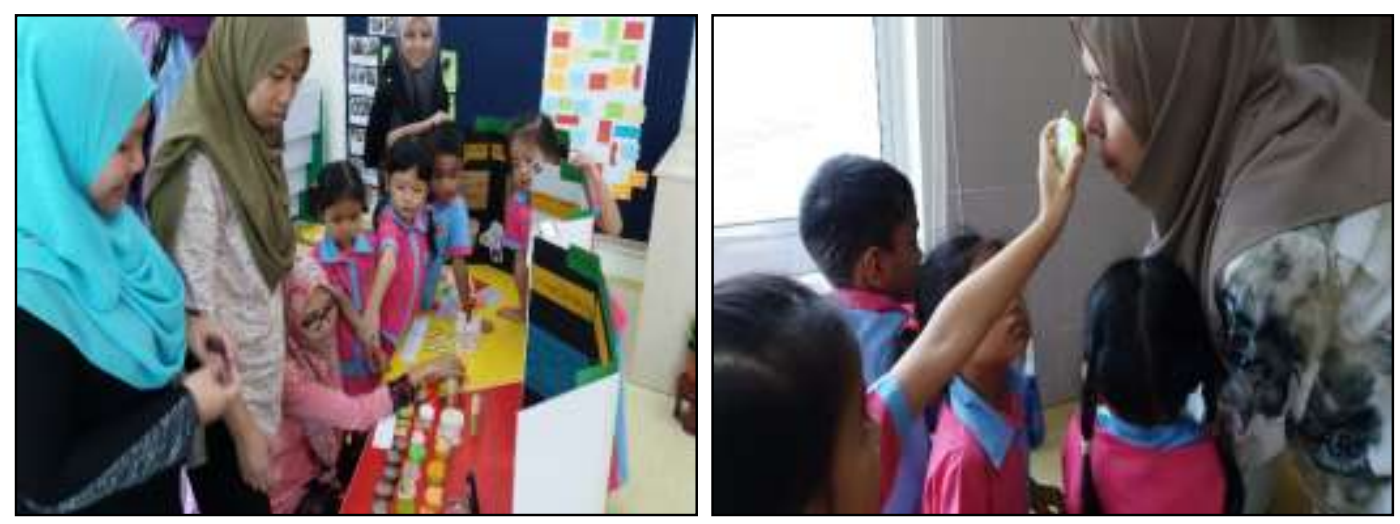

Gambar Foto 16: Tetamu mendapatkan informasi daripada kanak-kanak tentang projek sabun 


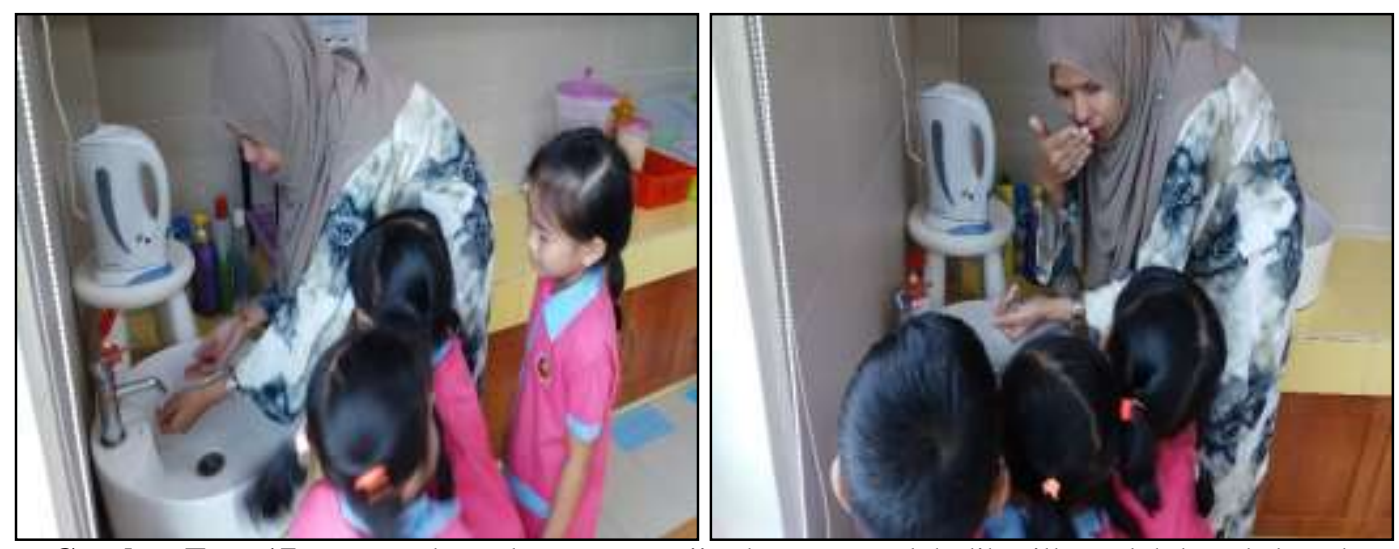

Gambar Foto 17: Tetamu berpeluang menguji sabun yang telah dihasilkan oleh kanak-kanak

\section{PERBINCANGAN DAN KESIMPULAN}

Inti pati hasil kajian ini menunjukkan bahawa terdapat empat elemen penyiasatan secara inisiatif kanak-kanak yang ditonjolkan menerusi projek darah dan sabun iaitu soalan kanakkanak, pemilihan bahan dan alat radas, tatacara pelaksanaan penyiasatan dan penghasilan projek.

Dapatan kajian mendapati soalan kanak-kanak merupakan elemen utama yang membawa kepada penerokaan dan penyiasatan secara inisiatif kanak-kanak. Perasaan ingin tahu menjadi pencetus kepada sesuatu aktiviti penyiasatan. Sehubungan itu, dapatan kajian mendapati terdapat pelbagai bentuk soalan yang dikemukakan antaranya soalan yang berbentuk ingin meneroka tentang sesuatu perkara dan soalan yang berbentuk ingin melakukan penyiasatan secara "hands-on” adalah selari dengan kajian Helavaara Robertson (2015).

Walau bagaimanapun, ada kalanya kanak-kanak tidak dapat mengemukakan soalan ataupun idea tentang sesuatu topik. Justeru, pendidik bertindak mencungkil idea kanak-kanak. Malah, peranan pendidik dianggap penting sebagai pemerhati serta memahami setiap tingkah laku kanak-kanak bagi menyokong pembelajaran secara inisiatif kanak-kanak (Musgrove \& Taylor, 2012).

Selain itu, pendidik juga berperanan dalam menentukan penyiasatan yang boleh dilaksanakan berdasarkan idea kanak-kanak. Hal ini dianggap penting oleh Helm dan Katz (2011) berikutan terdapat pelbagai perkara yang ingin diketahui oleh kanak-kanak. Justeru, soalan-soalan yang bernas dan boleh diuji sahaja dipilih oleh pendidik untuk disiasat oleh kanak-kanak bagi menyokong pembelajaran yang berkesan.

Lantaran itu, aktiviti menerusi Pendekatan Projek membuka peluang yang luas untuk kanak-kanak mengemukakan soalan, melontarkan idea, merancang aktiviti dan menjalankan penyiasatan yang mendalam terhadap sesuatu topik. Malah, kolaborasi di antara kanak-kanak dengan orang dewasa dapat membentuk pengalaman pembelajaran yang sangat bermakna serta membentuk pengetahuan baharu dalam pelbagai bidang seperti sains, matematik dan bahasa.

Sehubungan itu, dicadangkan supaya aktiviti pembelajaran secara inisiatif kanak-kanak diamalkan oleh semua pendidik di peringat awal kanak-kanak, khasnya dengan mengimplementasikan Pendekatan Projek. Hal ini berikutan Pendekatan Projek berpirinsipkan pembelajaran secara inisiatif kanak-kanak. Malah, menerusi aktiviti perbincangan, kajian 
lapangan, penyiasatan, paparan dan representasi dapat memberi impak positif terhadap perkembangan kognitif dan kemahiran sosial kanak-kanak.

\section{RUJUKAN}

Carr, M., \& Lee, W. (2012). Learning stories: Constructing learner identities in early education. New Delhi: Sage.

Creswell, J. W. (2014). A concise introduction to mixed methods research (4th ed.). New Delhi: Sage.

Harlen, W. (2014). Helping children's development of inquiry skills. Inquiry in Primary Science Education (IPSE), 1, 1, 5-19.

Helavaara Robertson, L., Kinos, J., Barbour, N., Pukk, M., \& Rosqvist, L. (2015). Child-initiated pedagogies in Finland, Estonia and England: Exploring young children's views on decisions. Early Child Development and Care, 185(11-12), 1815-1827. doi:10.1080/03004430.2015.1028392.

Helm, J. H \& Katz, G. (2015). Becoming young thinkers: Deep project work in the classroom. Teachers College Press.

Helm, J. H., \& Katz, L. G. (2011). Young investigators: The project approach in the early years. Teachers College Press.

Katz, L. G, \& Chard, S. C. (2000). Engaging children's minds: The project approach. Greenwood Publishing Group.

Katz, L. G, Chard, S. C. \& Kogan, Y. (2014). Engaging children's minds: The project approach-third edition. United Stated of America: Praeger.

Kementerian Pendidikan Malaysia. (2015a). Dokumen Standard Kurikulum dan Pentaksiran Sains Tahun 1. Putrajaya: Bahagian Pembangunan Kurikulum.

Merriam, S. B. (2009). Qualitative research: A guide to design and implementation (2 $2^{\text {nd }}$ ed.). USA: Jossey Bass.

Miles, M. B., \& Huberman, A. M. (1994). Qualitative data analysis: An expand sourcebook. (2 $\left.{ }^{\text {nd }} \mathrm{ed}\right)$. Thousand Oaks: California.

Musgrove, F., \& Taylor, P. H. (2012). Society and the teacher's role (RLE Edu N). Routledge.

Noriati Rashid, Pong, Y.B. \& Sharifah Fakhriah Syed Ahmad. (2012). Murid dan alam belajar. Selangor: Oxford Fajar.

Vygotsky, L. (1978). Interaction between learning and development. Readings on the development of children, 23(3), 34-41. Diperolehi daripada http://www.psy.cmu.edu/ siegler/vygotsky78.pdf

Yin, R. K. (2015). Qualitative research from start to finish. New York: The Guilford Publication. 